\title{
Commodity-led Development in Latin America
}

\author{
José Antonio Ocampo
}

\begin{abstract}
This chapter looks at the historical evolution of commodity dependence in Latin America, showing that dependence on natural resource-intensive exports increased during the 2003-13 commodity price boom after a period of export diversification that began in the mid-196os. It then analyses price dynamics, showing that commodity prices experienced both long-term trends, which were generally adverse for non-oil commodities through the twentieth century, and super-cycles of $30-40$ years. Based on that pattern, the author argues that the recent price collapse may be the beginning of a long period of weak commodity prices. Finally, the chapter demonstrates that the region has been unable to take full advantage of the benefits of its natural resource specialisation and has faced, in contrast, some negative Dutch Disease effects due to the aforementioned dependence. Latin America has, furthermore, been a victim of the macroeconomic vulnerabilities generated by commodity cycles, largely because it has failed to develop appropriate countercyclical macroeconomic policies.
\end{abstract}

\section{$1 \quad$ Introduction}

Commodities are at the heart of Latin America's economic development. Until the 1920 s they were the main engine of modern economic growth, and continued to make up an overwhelming proportion of the export basket until the 196os. The export diversification that has taken place since then, and that sped up with market reforms in the late twentieth century, did not fully replace this feature, except in a few countries. The recent commodity boom, which started in 2003-04 and lasted for a decade, generated what the UN Economic Commission for Latin America and the Caribbean has called a 're-primarisation' (or 're-commoditisation'), understood as a renewed growing share of natural resource goods in the export basket. Because of this, the collapse of the boom or 'super-cycle' of commodity prices, as it has been widely known, has generated major macroeconomic challenges in recent years, particularly for South America. 
The links between commodity dependence and development have been the subject of heated debate in Latin America, as well as in the global development literature. This relates to the capacity of commodity-led development to generate dynamic growth and, in that regard, whether such development benefits or harms the development of manufacturing and modern services. It also relates to how to manage the macroeconomic challenges associated with commodity price fluctuations, including the effects of the dependence of government revenues on taxes on commodity sectors and profits from state-owned enterprises active in those sectors (generally oil and minerals). The development advantages and disadvantages of commodities along with the macroeconomic challenges relate, in turn, to the dynamics of commodity prices, again a subject of heated debate since the formulation of what came to be known as the Prebisch-Singer hypothesis, according to which real commodity prices (relative to manufactures ${ }^{1}$ ) experience not only volatility but also an adverse longterm trend.

This chapter analyses these issues from the perspective of Latin America. It is divided into five sections, the first of which is this Introduction. The second takes a historical look at the evolution of commodity dependence in the region. The third analyses the dynamics of commodity prices. The fourth reviews the relevance of the debate on the macroeconomic effects of commodity dependence in Latin America. The last draws some brief conclusions.

\section{Changing Patterns of Commodity Dependence}

Commodity dependence has been an essential feature of Latin America's integration into the world economy since colonial times. When modern economic development took off, it was associated with the commodity expansion that took place in the late nineteenth and early twentieth centuries, which was brought to an end by the major shocks generated by the two world wars and the Great Depression of the 1930s. ${ }^{2}$ The collapse of commodity markets that accompanied this process led the region to a new stage of development, characterised by Cárdenas et al. (2000) and Bértola and Ocampo (2012) as 'state-led industrialisation', a term that captures this new phase in a better way than the traditional term 'import-substituting industrialisation', as the phase involved much more than import substitution.

1 In this chapter, the term manufacture $(s)$ refers to manufactured goods.

2 See Bértola and Ocampo (2012, Chapter 3) and Bulmer-Thomas (2014, Chapters 3-6). 
Commodity interests were never totally replaced, however. The basic reason for this is that commodity exports continued to make up the largest share of the export basket and the industrialisation process thus continued to rely heavily on the foreign exchange generated by these export sectors. Furthermore, the industrialisation of small economies did not go very far, and their export diversification since the 1950 s focused essentially on new commodities. The discovery of new resources had similar effects on larger economies, notably the major oil discoveries made in Mexico in the 1970s. Larger economies were, of course, more successful in their industrialisation drives and came to share in the growing world markets for developing country manufacturing exports since the mid-196os, and large and small economies started to benefit from growing intraregional trade in manufactures as a result of the integration processes launched during that same decade (the Latin American Free Trade Association, the Central American Common Market and the Andean Group).

State-led industrialisation was characterised by a significant dependence on domestic markets, high levels of protection, and a fall in Latin America's share in world trade, to slightly more than 4 per cent in the early 1970s, about half the level reached in the period $1925^{-29}$. The region's falling share in world commodity markets was the main reason for this decline (Ffrench-Davis et al., 1998; Bértola and Ocampo, 2012, Table 4.10), and was associated with both external and domestic factors. Among the external factors, the most important was the boom in Middle East oil production from the early 196os to the early 197os, which led to a fall in Latin America's (particularly Venezuela's) share in world oil exports. Agricultural exports were also hurt by protectionism in developed countries, which hit Argentina, Cuba and Uruguay particularly badly. Among the domestic factors, the most important was explicit or implicit (via differential exchange rates) economic policy discrimination against traditional agricultural export products, especially coffee and sugar, though it must be underscored that policies also protected agricultural production that competed with imports. ${ }^{3}$

An additional feature of state-led industrialisation was restrictions on foreign direct investment (FDI) in the natural resource and infrastructure sectors of several countries, and the growing role played by state-owned enterprises in those sectors. This included the nationalisation of oil in Mexico in 1938, which would be followed in later decades by that of tin in Bolivia, copper in Chile and

3 This is a more appropriate interpretation of the information provided by Anderson and Valdés (2008) than the reading that points to a widespread anti-agricultural bias. See, for example, figure 1.3 of that study, which shows that almost all products that competed with imports were protected. 
oil in Venezuela, but also by the creation of state-owned enterprises active in the oil and mining sectors in many other countries. International regulation of commodity markets was also an important feature-particularly after the collapse of commodity prices in the second half of the 1950s-with the regulation of coffee markets by both producing and consuming nations being perhaps the best example, starting with the first International Coffee Agreement in 1962. In turn, Venezuela became the driving force behind the creation of the Organization of the Petroleum Exporting Countries (OPEC), which took place in 1960.

The last two decades of the twentieth century were characterised by the effects of a major collapse of commodity prices (see Section 3 of this chapter), the Latin American debt crisis of the 1980s, which was in part fed by that price collapse, and by the market reforms introduced in a pioneering manner by Southern Cone countries (notably Chile) in the second half of the 1970s and on a broader regional basis since the mid-1980s. Market reforms tended to reinforce comparative advantage in natural resource sectors, and included the opening up of oil and mineral sectors to private investors in countries that had nationalised these sectors, and the abandonment of commodity price-stabilisation schemes. Mexico, until the recent reforms, was the exception with regard to the opening up of its oil sector. Bolivia strengthened the control of its hydrocarbon sector in the hands of state-controlled firms in 2006, as did Argentina in $2012,{ }^{4}$ and state-owned enterprises continued to play an important role in the oil and mineral sectors in several countries (notably in the copper sector in Chile). In relation to commodity agreements, the collapse of the International Coffee Agreement in 1989 was perhaps the most important event, but also significant was the growing incapacity of OPEC to regulate oil prices from the early 1980 s on, which ended with the collapse of those prices in 1986.

Despite the reinforcement of the traditional comparative advantages generated by market reforms, the diversification of Latin American exports away from commodities, which had started in the mid-196os, continued during the last two decades of the twentieth century (Figure 4.1). A major reason for this diversification trend was the collapse of commodity prices that took place during this period (see next section). The signing of the North American Free Trade Agreement (NAFTA), was an essential part of this process, as Mexico led the transformation away from primary goods and natural resource-based manufactures. The revitalisation of regional integration processes in the late 1980s/early 1990s, which included the creation of MERCOSUR (Southern

4 In the case of both Bolivia and Argentina, earlier privatisations were reversed in the years indicated. Although in both cases these policy reversals were called 'nationalisation' they really involved majority control by the state rather than full nationalisation. 


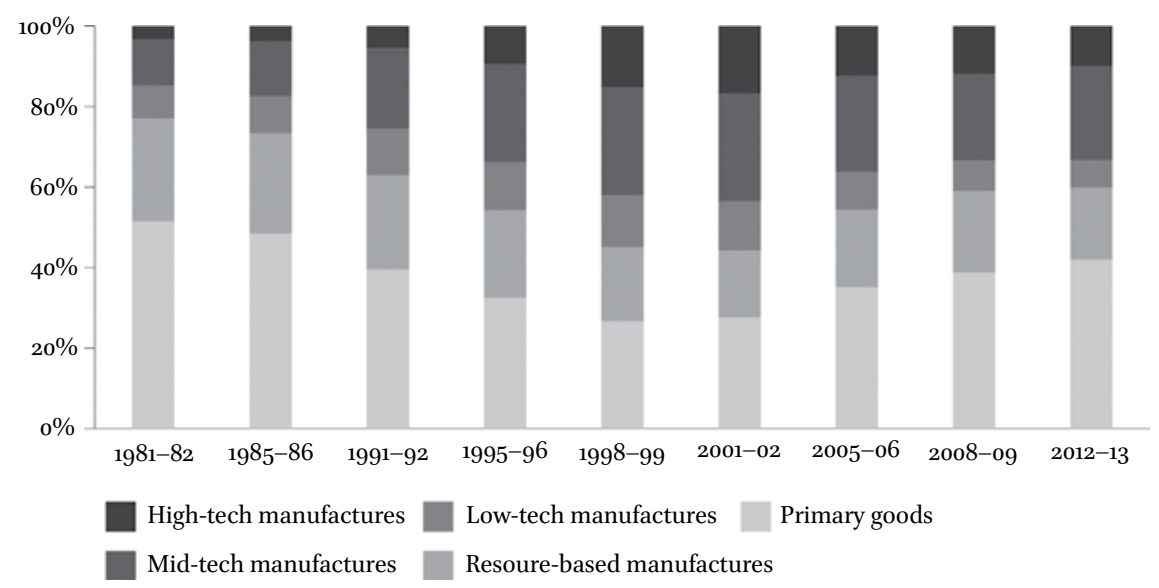

FIGURE 4.1 Natural resource and technological contents of Latin American exports. SOURCE: ECLAC (2015b).

Common Market) in 1991, tended to support diversification, given the high manufacturing intensity of intraregional trade. The exports of intermediateand high-technology manufactures grew quite rapidly during the 1990-97 expansion, and at a somewhat slower rate at the turn of the century as intraregional trade was hit hard by the significant crisis that the region was facing once again, and Mexican exports were hurt by the us slowdown in the early years of the new millennium.

This process was followed by a significant re-primarisation of the structure of exports, particularly as a result of the commodity price boom that started in 2003-04 and lasted for about a decade. This re-primarisation was enhanced by growing trade with China, ${ }^{5}$ which became a major trading partner of Latin America in the first decade of the twenty-first century, particularly after the 2007-09 North Atlantic financial crisis. ${ }^{6}$ As Figure 4.2 indicates, aside from intraregional trade and exports to the us (though not if Mexico is excluded $^{7}$ ), Latin American exports are highly natural resource dependent, those to China being the most dependent of all, representing over 9o per cent of

5 See, in this regard, several contributions by Kevin Gallagher-including his recent book (Gallagher, 2016)—and ECLAC (2015a).

6 This is the term I will use here instead of 'global financial crisis', because although it had global effects the crisis was concentrated in the us and Western Europe.

7 Indeed, according to ECLAC, if we exclude Mexico, primary goods and natural resourcebased manufactures represented 68.3 per cent of exports to the us in 2014 vs. 29.9 per cent if Mexico is included. 


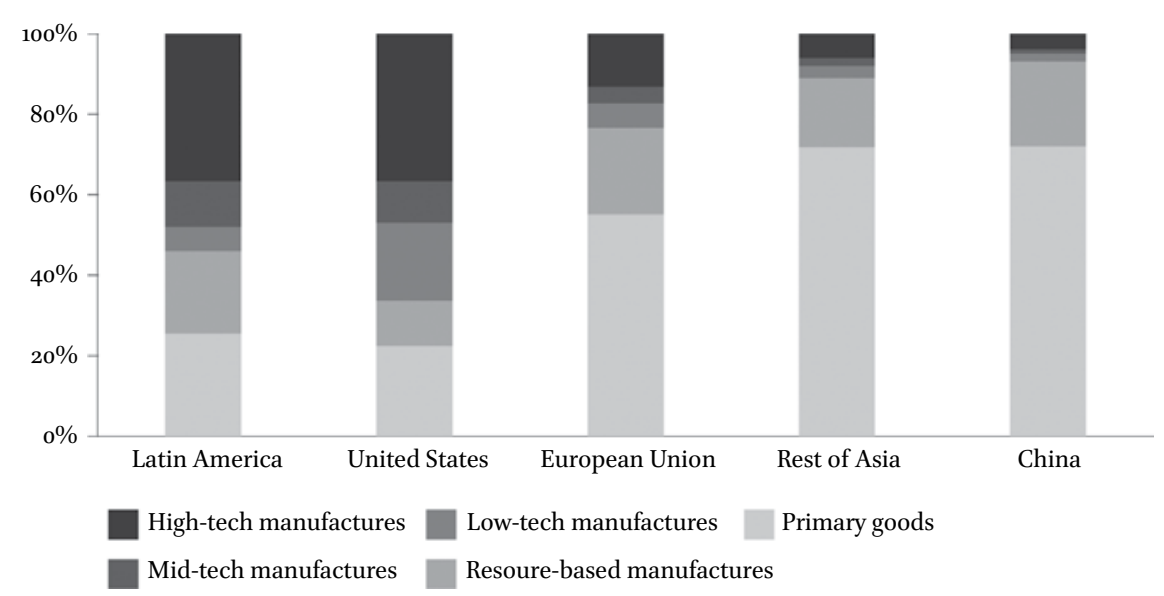

FIGURE 4.2 Latin American natural resource exports by destination, 2013. SOURCE: ECLAC (2015a).

sales to the Asian giant in 2013. Booming Chinese imports also supported the re-primarization process by weakening manufacturing sectors in several (or most) countries.

The impact of market reforms and other factors affecting export structures was diverse across the region. Two basic specialisation patterns have evolved since the 199os, which broadly follow a 'North-South' divide (ECLAC, 2001; Bértola and Ocampo, 2012, Chapter 5). The 'Northern' pattern is characterised by a bigger share of manufacturing exports, a large part of them containing a significant number of imported inputs and exhibiting limited domestic value-added (in its most extreme form, maquila-i.e., assembling of imported parts) and destined for the us market. The 'Southern' pattern has changed less, and is made up of a combination of extra-regional export of commodities, natural-resource-based manufactures and a much more diversified range of products (including many with greater technological content) that are traded within the region. Brazil is positioned somewhere between the two groups, since it already had a much more diversified export structure (including some technology-intensive manufactures) than other South American countries prior to the liberalisation processes. ${ }^{8}$ There is also a third specialisation pattern, exhibited by a few smaller economies and characterised by a large share of service exports, which prevails in Panama (transport and financial services), Cuba and the Dominican Republic (tourism in both cases).

8 In fact, in 1990 Brazil's and Mexico's export structures were not very different in terms of this classification (see Bértola and Ocampo, 2012, Table 5.5). 
Among South American countries, there is also a significant difference between the specialisation pattern of the Andean economies, from Venezuela to Chile, which depend on oil, gas and minerals, ${ }^{9}$ and that of the rest of South America, which is agriculture-based (Table 4.1). In any case, agricultural exports make up an important share of total exports in some Andean countries (particularly Ecuador and Chile, but also others, with the exception of Venezuela) and Brazil also has important mineral exports, particularly iron ore. In the 'Northern' pattern, Mexico is an important oil exporter, and Cuba and the Dominican Republic have mining exports, but the majority of commodity exports are made up of agricultural goods, particularly in the case of Central American countries.

TABLE 4.1 Natural resource dependence of Latin American exports

\begin{tabular}{|c|c|c|c|c|c|c|c|c|c|c|c|c|}
\hline & \multicolumn{3}{|l|}{ Fuels } & \multicolumn{3}{|c|}{ Minerals } & \multicolumn{3}{|c|}{ Agriculture } & \multicolumn{3}{|l|}{ Total } \\
\hline & 1995 & 2003 & 2013 & 1995 & 2003 & 2013 & 1995 & 2003 & 2013 & 1995 & 2003 & 2013 \\
\hline Arge & $10.3 \%$ & $17.1 \%$ & $4.6 \%$ & $1.7 \%$ & $3.4 \%$ & $5 \%$ & $54.1 \%$ & $50.5 \%$ & $54.8 \%$ & $66.2 \%$ & $71.0 \%$ & $65.0 \%$ \\
\hline Bolivia & $10.9 \%$ & $33 \cdot 3 \%$ & $53.8 \%$ & $40.1 \%$ & $16.7 \%$ & $23.8 \%$ & $33.4 \%$ & $33.1 \%$ & $18.3 \%$ & $84.3 \%$ & $83.1 \%$ & $95.9 \%$ \\
\hline Brazil & $0.9 \%$ & $5.2 \%$ & $7 \cdot 4 \%$ & $11.3 \%$ & $9.1 \%$ & $18.1 \%$ & $33 \cdot 7 \%$ & $33.1 \%$ & $37 \cdot 4 \%$ & $45 \cdot 9 \%$ & $47 \cdot 4 \%$ & $62.9 \%$ \\
\hline Chile & $0.2 \%$ & $2.7 \%$ & $0.9 \%$ & $49 \cdot 5 \%$ & $42.3 \%$ & $59.0 \%$ & $37.2 \%$ & $36.7 \%$ & $27.1 \%$ & $86.9 \%$ & $81.7 \%$ & $87.0 \%$ \\
\hline Colombia & $27.2 \%$ & $37.2 \%$ & $66.8 \%$ & $6.8 \%$ & $6.2 \%$ & $5.1 \%$ & $36.2 \%$ & $22.9 \%$ & $11.4 \%$ & $70.2 \%$ & $66.3 \%$ & $83.3 \%$ \\
\hline Ecuador & $35.1 \%$ & $43.2 \%$ & $56.5 \%$ & $2.5 \%$ & $0.4 \%$ & $2.7 \%$ & $54.8 \%$ & $46.3 \%$ & $34.5 \%$ & $92.4 \%$ & $89.9 \%$ & $93.8 \%$ \\
\hline Paraguay & $2.7 \%$ & $6.8 \%$ & $15.4 \%$ & $0.3 \%$ & $0.4 \%$ & $1.4 \%$ & $80.3 \%$ & $82.2 \%$ & $74.4 \%$ & $83 \cdot 3 \%$ & $89.4 \%$ & $91.2 \%$ \\
\hline Peru & $4.9 \%$ & $7 \cdot 4 \%$ & $13.0 \%$ & $50.2 \%$ & $53 \cdot 7 \%$ & $58.1 \%$ & $31.3 \%$ & $22.3 \%$ & $17.1 \%$ & $86.4 \%$ & $83.4 \%$ & $88.2 \%$ \\
\hline Urugu & $1.0 \%$ & $1.6 \%$ & $0.5 \%$ & $0.9 \%$ & $1.5 \%$ & $1.6 \%$ & $59.1 \%$ & $63.7 \%$ & $74.9 \%$ & $61.0 \%$ & $66.8 \%$ & $77.0 \%$ \\
\hline Venezuela & $73.6 \%$ & $78.9 \%$ & $91.4 \%$ & $7 \cdot 5 \%$ & $5 \cdot 5 \%$ & $1.0 \%$ & $3.2 \%$ & $1.7 \%$ & $0.3 \%$ & $84.2 \%$ & $86.2 \%$ & $92.7 \%$ \\
\hline Costa Rica & $0.4 \%$ & $0.3 \%$ & $0.1 \%$ & $1.2 \%$ & $0.7 \%$ & $1.0 \%$ & $61.5 \%$ & $30.4 \%$ & $22.3 \%$ & $63.1 \%$ & $31.4 \%$ & $23.4 \%$ \\
\hline Cuba & $0.3 \%$ & $1.1 \%$ & $9 \cdot 4 \%$ & $15.5 \%$ & $35.0 \%$ & $19.7 \%$ & $76.8 \%$ & $46.0 \%$ & $30.6 \%$ & $92.6 \%$ & $82.1 \%$ & $59.8 \%$ \\
\hline Dominican & $0.0 \%$ & $0.1 \%$ & $3 \cdot 3 \%$ & $2.2 \%$ & $1.8 \%$ & $16.1 \%$ & $16.4 \%$ & $14.8 \%$ & $22.6 \%$ & $18.6 \%$ & $16.6 \%$ & $42.0 \%$ \\
\hline \multicolumn{13}{|l|}{ Republic } \\
\hline El Salvador & $0.2 \%$ & $1.7 \%$ & $1.9 \%$ & $1.9 \%$ & $1.6 \%$ & $2.0 \%$ & $45 \cdot 3 \%$ & $19 \cdot 3 \%$ & $22.8 \%$ & $47 \cdot 5 \%$ & $22.5 \%$ & $26.7 \%$ \\
\hline
\end{tabular}

9 This pattern developed relatively late in Colombia. Although oil and minerals (coal, nickel and gold) increased since the 1980s, they only surpassed the share of agriculture in the second half of the 199os and came to represent more than half of exports only after 2008. 
TABLE 4.1 Natural resource dependence of Latin American exports (cont.)

\begin{tabular}{|c|c|c|c|c|c|c|c|c|c|c|c|c|}
\hline & \multicolumn{3}{|l|}{ Fuels } & \multicolumn{3}{|c|}{ Minerals } & \multicolumn{3}{|c|}{ Agriculture } & \multicolumn{3}{|l|}{ Total } \\
\hline & 1995 & 2003 & 2013 & 1995 & 2003 & 2013 & 1995 & 2003 & 2013 & 1995 & 2003 & 2013 \\
\hline Guatemala & $1.6 \%$ & $6.1 \%$ & $4.0 \%$ & $0.4 \%$ & $0.4 \%$ & $5.8 \%$ & $61.3 \%$ & $43.0 \%$ & $50.1 \%$ & $63.4 \%$ & $49 \cdot 4 \%$ & $59.9 \%$ \\
\hline Honduras & $0.2 \%$ & $0.1 \%$ & $3.9 \%$ & $0.7 \%$ & $3 \cdot 5 \%$ & $7.8 \%$ & $55 \cdot 7 \%$ & $32.4 \%$ & $42.3 \%$ & $56.6 \%$ & $36.0 \%$ & $54.0 \%$ \\
\hline Mexico & $10.3 \%$ & $11.2 \%$ & $12.8 \%$ & $3.1 \%$ & $1.3 \%$ & $4.6 \%$ & $9.0 \%$ & $6.0 \%$ & $6.6 \%$ & $22.4 \%$ & $18.5 \%$ & $24.0 \%$ \\
\hline Nicaragua & $0.6 \%$ & $0.7 \%$ & $0.5 \%$ & $2.8 \%$ & $4.4 \%$ & $10.4 \%$ & $74.6 \%$ & $56.5 \%$ & $42.7 \%$ & $78.0 \%$ & $61.6 \%$ & $53.5 \%$ \\
\hline Panama & $3.0 \%$ & $8.1 \%$ & $21.9 \%$ & $1.9 \%$ & $2.0 \%$ & $4.7 \%$ & $33.5 \%$ & $32.3 \%$ & $15.8 \%$ & $38.4 \%$ & $42.4 \%$ & $42.5 \%$ \\
\hline Latin & $13 \cdot 3 \%$ & $15.2 \%$ & $20.5 \%$ & $9.8 \%$ & $7 \cdot 3 \%$ & $13.6 \%$ & $26.7 \%$ & $20.7 \%$ & $21.8 \%$ & $49.8 \%$ & $43.1 \%$ & $55 \cdot 9 \%$ \\
\hline America & & & & & & & & & & & & \\
\hline Memo: & $15.0 \%$ & $17.9 \%$ & $23.1 \%$ & $5 \cdot 3 \%$ & $4.4 \%$ & $6.7 \%$ & $12.7 \%$ & $8.8 \%$ & $8.0 \%$ & $33.1 \%$ & $31.1 \%$ & $37.8 \%$ \\
\hline
\end{tabular}

SOURCE: UNCTAD.

Notes: Fuels, SITC 3; Minerals, SITC $27+28+68+667+971$; Agriculture (includes fishing and forestry), SITC $0+1+2-27-28+4$.

\section{The Dynamics of Commodity Prices}

There has been significant debate regarding commodity prices since the formulation of the Prebisch-Singer hypothesis in 1950, according to which commodity prices tend to deteriorate in the long term relative to those of manufactures (Prebisch, 1973; Singer, 1950). This was, of course, a major break with the classical view of David Ricardo, according to which relative commodity prices tend to rise as economies are forced to exploit less productive resources and land rents are pushed up. The Prebisch-Singer hypothesis involved two complementary ideas (Ocampo, 1986). The first was that the lower income and price elasticities of demand for primary goods would tend to depress their relative prices as the world economy expanded (or, alternatively, constrain the growth rate of natural resource-intensive economies). The second was that of asymmetries in the labour markets of advanced versus developing countries, which implied that technological progress in manufactures would tend to be reflected in increasing real wages in developed countries, whereas it would tend to depress the price of commodities in the developing world, given the pool of unskilled labour available in developing countries. This 
second hypothesis was also supported by Lewis' (1969) analysis of the pressure on commodity prices generated by surplus labour in developing countries. The Prebisch-Singer hypothesis was the subject of heated debate following its initial formulation and was largely discarded both on empirical and analytical grounds. Interestingly, the original hypothesis was revived by the work of Grilli and Yang (1988) at the World Bank, who showed that real commodity prices had actually declined through the twentieth century. These findings triggered a significant flow of empirical contributions to the revived and continuing debate.

An older set of hypotheses relates to the existence of long-term cycles of economic activity, foreign trade and prices, related to the works of Nikolai Kondratiev and Joseph Schumpeter. Schumpeter associated them with clusters of technological innovation that come, in his view, in waves (see, for example, Schumpeter, 1939). In empirical terms, the tendency of the price of commodities relative to manufactures to follow long waves was later highlighted by Lewis (1978), but received only limited attention. ${ }^{10}$

As we shall see, the factors underlying such long-term trends and cycles vary through time, giving rise to specific features in different periods. In recent times, the dominant factor has been, of course, the rising Chinese demand for commodities, but also the effect of a slowdown of world economic growth since the North Atlantic financial crisis, particularly in developed countries.

The dynamics of commodity prices can be analysed using several alternative methodologies. A first approach studies whether long-term dynamics should be understood as the result of a steady trend or of structural breaks in the price series. Using this methodology, Ocampo and Parra-Lancourt (2010) conclude that the fall in real non-oil commodity prices through the twentieth century that Grilli and Yang had identified was essentially the result of two strong adverse shocks: a sudden one in the early 1920 s and a second more gradual one in the 1980s. A second methodology involves the decomposition of price dynamics into a trend of long- and short-term cycles. This is the methodology used by Erten and Ocampo (2013), on which I will focus here. A third one analyses the links between commodity and other asset prices, which is particularly important given the recent 'financialisation' of commodity markets. This approach has been the subject of an extensive literature; however, since its focus is on the very short-term dynamics of commodity prices, I shall not analyse it here.

The decomposition of commodity price trends into their different components is summarised in Figure 4.3. As the figure indicates, real non-oil 
A. Real non-oil commodity price components, total index

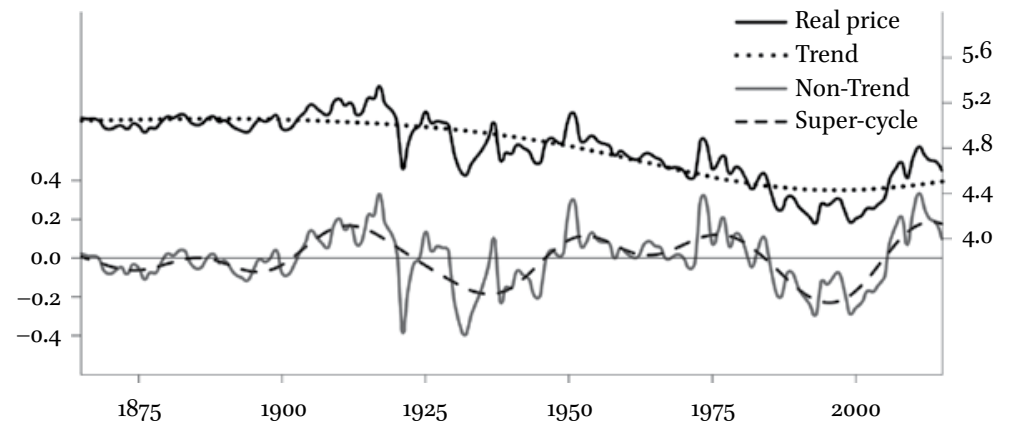

B. Real crude oil price components

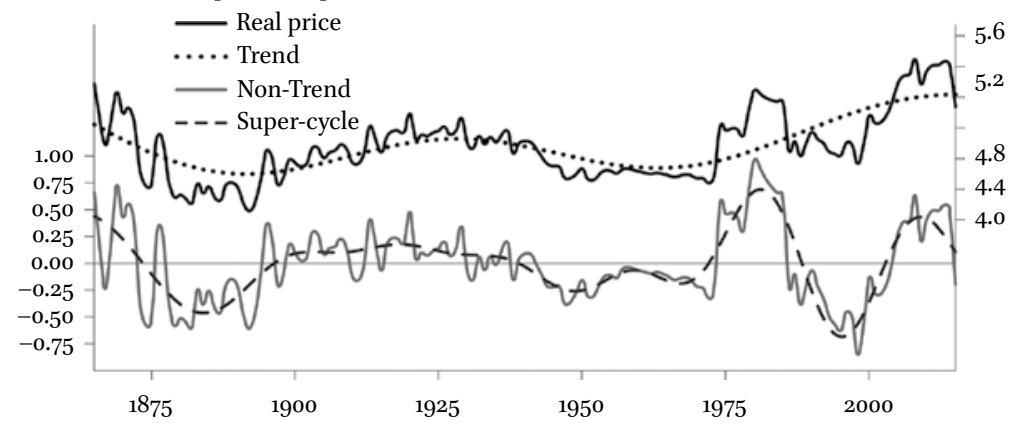

C. Super-cycle components for non-oil subsidies

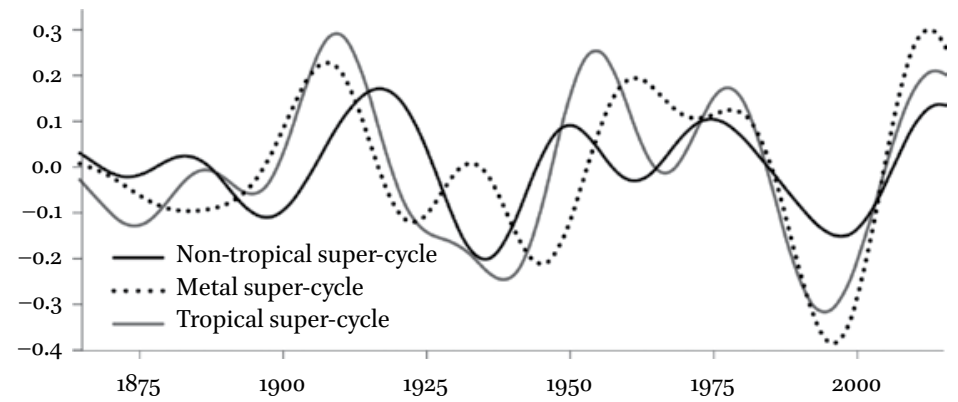

D. Super-cycle components for non-oil and oil prices

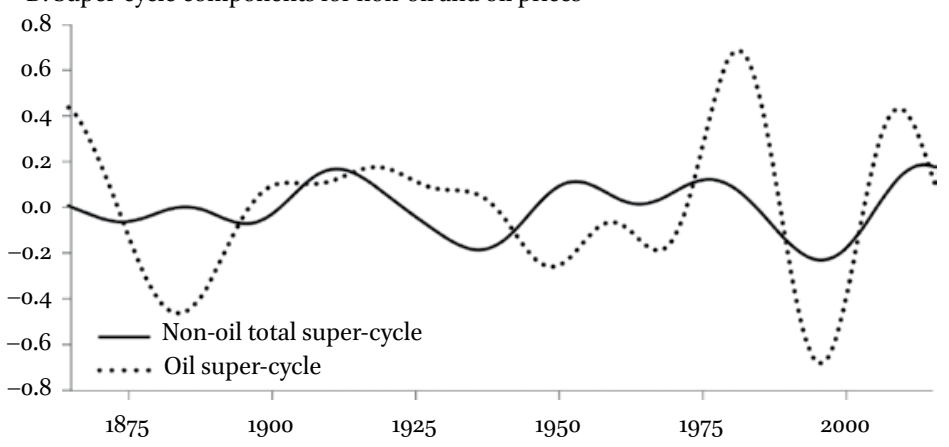

FIGURE 4.3 Long-term trends and super-cycles of commodity prices. SOURCE: UPDATED EXERCISES FROM ERTEN AND OCAMPO (2013). 
commodity prices (deflated by the manufacturing unit value in international trade) experienced a downward trend through most of the twentieth century and a slight upward trend in the early twenty-first century (Figure 4.3A). An analysis of these trends by commodity groups shows that the downward trend was longer and stronger for tropical agricultural goods (114 years with an accumulated fall of 67 per cent) than for non-tropical agriculture (62 years with a total fall of 47 per cent) and metals (93 years and 48 per cent). This downward trend was followed by a long-term rise in metal prices since the mid-197os and by a stagnation of the adverse trend of agricultural prices since around the turn of the century (Erten and Ocampo, 2013, Table 1).

In turn, non-oil commodities have experienced four long-term cycles (which I will call super-cycles in the rest of this chapter) of 30-40 years since the late nineteenth century - with the last still ongoing - with a large overlap among different commodity groups (Figure $4.3 \mathrm{C}$ ). The overlap of these super-cycles is related to the fact that they are largely determined by trends in world GDP. The effects of trends in world demand are also reflected in the fact that supercycles show fairly similar peaks but that the downward trend is stronger in periods where world demand has been weak (1920s-30s and 1980s-9os) than when it has been stronger (second half of the 1950s and 1960s). Finally, the volatility of the short-term cycles was particularly intense in the interwar years of the twentieth century.

Long-term trends of non-oil prices through the twentieth century provide, therefore, some support to the Prebisch-Singer hypothesis. This is also reflected in the fact that the means and peaks during the different super-cycles also show a downward trend. However, the trends in the late nineteenth and early twentieth centuries, as well as that of the early twenty-first century, indicate that this is not an inevitable outcome. More generally, as Erten and Ocampo (2013) argue, the tendency for primary commodity prices to deteriorate relative to manufactured goods is not a persistent effect, but rather an evolving dynamic dependent on global demand trends and the effects of technological innovations, both of which are behind the dynamics of the different super-cycles.

Oil prices did not show a similar pattern to that of non-oil prices until the 1960s. The long-term downward trend was shorter and weaker (37 years, from 1925 to 1962 , with a 33 per cent accumulated reduction) and there has been a strong upward trend since the 1970 (Figure 4.3.B). However, what is interesting is both the strong coincidence of the last two super-cycles of oil and non-oil commodities - again, with the last one still ongoing — and the stronger intensity of the oil super-cycle (Figure 4.3.D). 
Indeed, if we look at the last two super-cycles, that for oil has been more intense (a coefficient of variation of 41 per cent in the period 1970-2003 and 26 per cent in $2003^{-1} 5^{11}$ ) than that for non-oil commodities (21 per cent and 16 per cent, respectively). And within the super-cycle for non-oil commodities, the most intense was that for tropical agricultural goods in the period 1970-2003 (35 per cent vs. 20 per cent for non-tropical agricultural goods and 17 per cent for metals) and metals in the period $2003-15$ (25 per cent vs. 22 per cent for tropical agricultural goods and 15 per cent for non-tropical agricultural goods). Viewed as a whole, oil prices have been the most unstable, whereas non-tropical agricultural prices have been the most stable.

This also implies that, as measured by the peak price reached, the recent commodity boom (2003-13) was more intense for oil and metals than for agricultural goods, and stronger for non-tropical than for tropical agricultural goods; indeed, only in 2011 did real tropical agricultural prices reach a level close to that of the 1970s (Figure 4.4). The boom of all commodity prices was interrupted during the worst phase of the North Atlantic financial crisis- the months following the collapse of the investment bank Lehman Brothers in September 2008 - but soon resumed. Strong Chinese demand was the essential element of both the long commodity boom and the rapid recovery after the

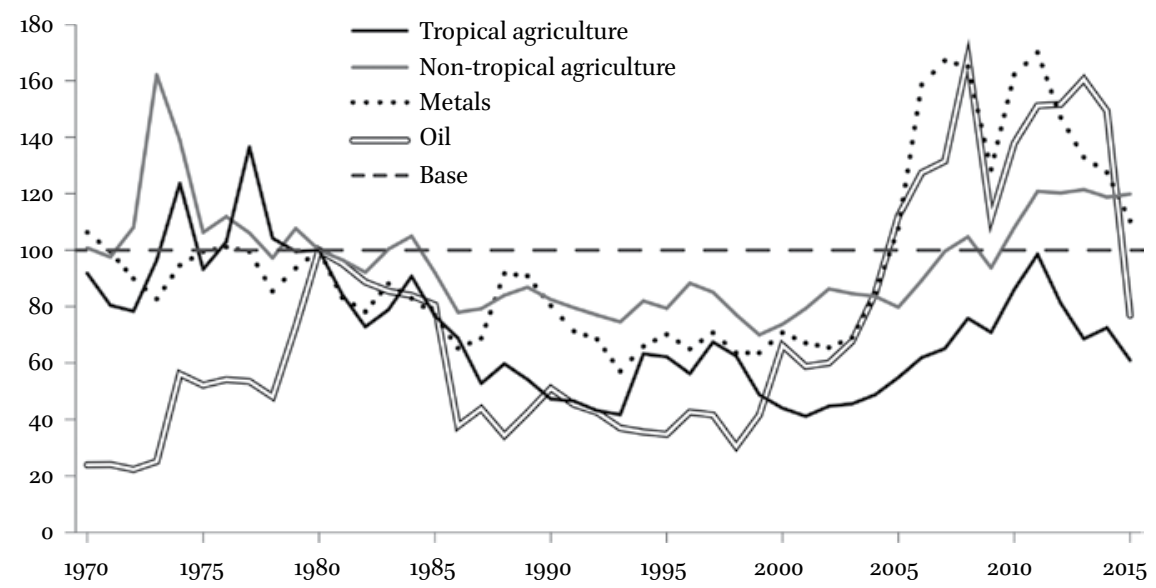

FIGURE 4.4 Real non-oil commodity price $(1980=100)$. SOURCE: UPDATED SERIES FROM OCAMPO AND PARRA (2010) WITH THE SAME SOURCES AND METHODOLOGY. COMMODITY PRICES ARE DEFLATED BY THE MANUFACTURING UNIT VALUE ESTIMATED BY THE WORLD BANK.

11 I take a common 1970-2003 period as a reference, though the super-cycle of oil prices started somewhat later. And, again, the most recent period corresponds to an as-yetincomplete cycle. 
North Atlantic crisis. The peaks for oil and metal prices prior to and after that crisis were quite similar, whereas they were stronger after the boom for the two agricultural commodity groups. The downward trend has been visible for non-oil commodities since 2012 but was a gradual process, ${ }^{12}$ whereas that for oil came late and abruptly in mid-2014.

The performance of the different commodity groups was reflected in the patterns of the terms of trade for different Latin American countries. The improvement in the terms of trade from 2003 to either 2008 or 2013 was strongest for the oil and mineral exporting economies, which, as indicated above, are the Andean countries (Figure 4.5). These were followed by the two major agricultural exporters, Brazil and Argentina. Other South American countries (Paraguay and Uruguay) and Mexico were in a fairly neutral position, whereas all the small economies of Central America, and the Dominican Republic, were clear losers, as the rise in oil prices dominated any positive effect they experienced as agricultural exporters. It can be added that the recent collapse in commodity prices has had exactly the opposite effect on

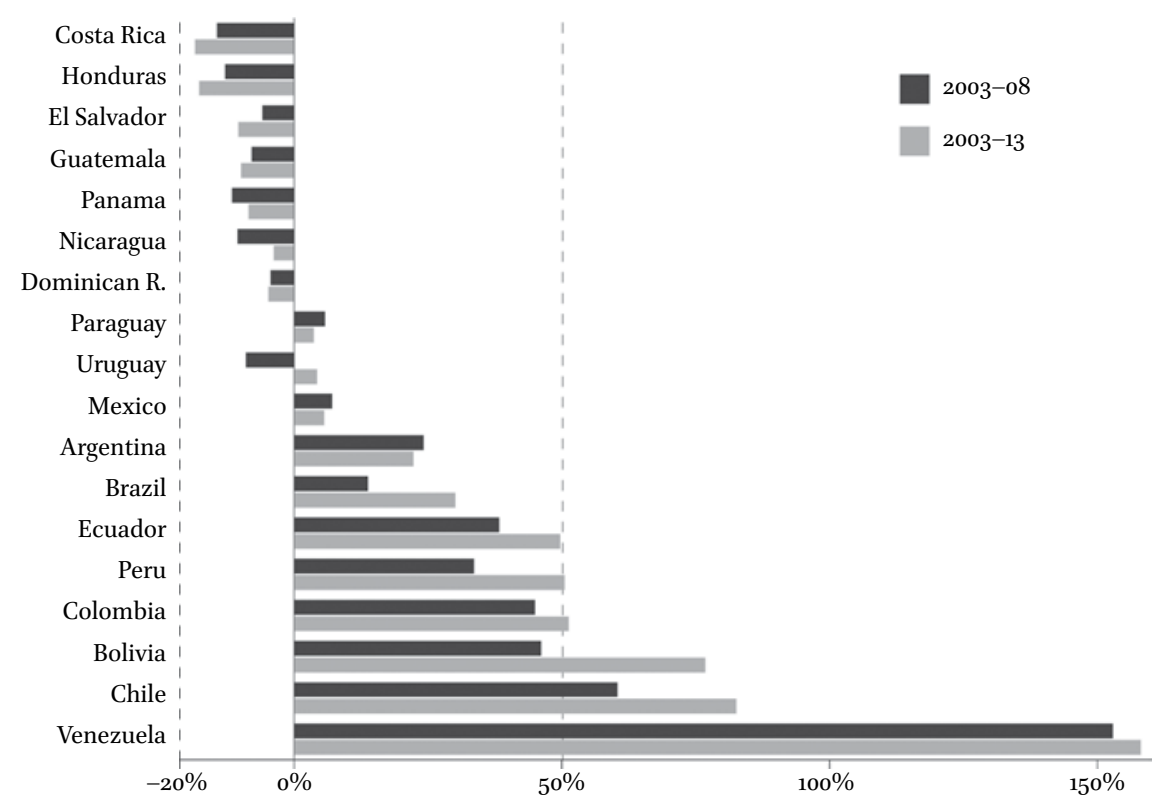

FIGURE 4.5 Terms of trade gains and losses during the 2003-13 commodity boom. SOURCE: AUTHOR'S ESTIMATES BASED ON ECLAC DATA.

12 A partial exception is non-tropical agricultural goods, but that case reflects the diverging prices of individual commodities. 
the terms of trade of different countries (ECLAC, 2015b, Table A-7). Interestingly, in the case of commodity exporters who are also oil importers, the stronger fall in oil prices has ended up mitigating the fall of other commodity prices (Chile) or even generating an improvement in the terms of trade (Paraguay and Uruguay).

A major implication of the dynamics of commodity prices is that the positive expectations that were built up during the boom were defeated by recent trends. These expectations were based on the view that the mix of strong Chinese demand, the gradual exhaustion of new oil and mineral resources, and the effects of climate change were bound to be reflected in a Ricardian era of rising natural resource scarcity and high commodity prices. Long-term trends since the late twentieth century do give some support to the idea of positive patterns of commodity prices, and certainly show that the PrebischSinger hypothesis is not an inevitable trend. However, through the prism of the last few years, the predictions of persistently high commodity prices have turned out to be wrong and, particularly, the strong cyclical pattern has been shown to be an essential characteristic of commodity prices. Indeed, given the slowdown of global economic growth since the North Atlantic financial crisis, a slowdown that is likely to last, if the pattern of past super-cycles prevails, we may be at the beginning of a long period of weak prices.

\section{4}

\section{Macroeconomic Effects of Commodity Dependence}

\subsection{The Basic Relationships}

The macroeconomic effects of commodity dependence should be analysed from both a short- and a long-term perspective. The short-term dimensions are closely associated with the cyclical patterns of commodity prices, which generate fluctuations of income levels that would tend to be transmitted and multiplied through their effects on aggregate domestic demand. The procyclical patterns of investment are generally strong, and those of consumption have become more important in recent decades, reflecting the strong volatility of economic growth that has characterised Latin America since the 1980s. In turn, the cyclical patterns of commodity prices are enhanced by those of both external and domestic finance. In the case of external finance, emerging and developing countries tend to experience a strong procyclical pattern, both in terms of the availability of finance and of risk margins and thus the cost of financing (higher costs of financing during downswings). In commodityexporting countries, these cycles tend to follow those of commodity prices.

The cyclical behaviour of real exchange rates generated by these external cycles tends to enhance the fluctuations of aggregate demand in economies 
with net liabilities in foreign currency, as real exchange rate appreciation during booms generates wealth windfall gains that enhance spending; whereas depreciation during crises generates a wealth loss that accentuates the contraction of spending. The distributive effects go in the same direction: if the appreciation benefits workers and the depreciation hurts them, there will also be procyclical effects, given the higher propensity to spend out of wages. The effects of real exchange rate fluctuations on the current account (non-primary exports decreasing and imports rising during commodity booms, and the opposite evolution occurring during crises) can be countercyclical. However, if there is an initial surplus during the boom (the situation in the period 2003-04) or an initial deficit during the crisis (conditions in the period 2013-14), the initial effect is also procyclical and the countercyclical effects come with a lag.

In terms of cyclical behaviour, it is critical whether authorities adopt a countercyclical stance, as macroeconomic policy would recommend (particularly its Keynesian variants), or prefer a procyclical pattern, associated with either economic or political economy pressures, or both. In this regard, the procyclical effects of finance may be difficult to counteract through monetary policy if there is free movement of capital, reflecting the known 'trilemma' of open economic macroeconomics; but even if countries actively manage the capital account with macro-prudential policies, it may be difficult for them to isolate themselves from those procyclical external financial pressures. In turn, the dependence of public sector finance on revenues generated by commodity sectors generates a procyclical pattern of fiscal revenues that may be transmitted to public sector spending.

The long-term effects are associated, in turn, with whether the commodity sectors generate strong or weak linkages with other economic activities, and whether commodity dependence is associated with strong or weak productivity growth. In the classical analyses of commodity dependence, associated with Singer and Prebisch, among others, the basic arguments were that manufacturing both generates stronger linkages and is a stronger mechanism of transmission of technical progress. In the more recent literature, this is confirmed by the fact that rapid economic growth in emerging and developing countries continues to be associated with industrialisation drives, an area in which Latin America's performance (a few countries aside) has been dismal for several decades. ${ }^{13}$ In favour of commodity dependence, it can be said that the opportunities for technical progress and linkages with both manufacturing and service sectors were behind commodity-dependent developed countries'

13 See Rodrik (2014) at the global level, Hausmann (2011) in relation to Latin America, and Palma (2011) for a comparative perspective. An excellent macroeconomic perspective on these issues is provided by Bresser-Pereira et al. (2015). 
capacity to prosper. ${ }^{14}$ In recent years, perhaps the best defence of the development opportunities provided to Latin America by its natural resources is that of Pérez (2010). She argues that today there are ample technological opportunities associated with biotechnology, nanotechnology and environmentally friendly products - opportunities to exploit the whole value chain of natural resourceintensive sectors, and strong complementarities with Asia (although now with lower prices). In contrast, her (correct) evaluation is that Latin America is too far behind in other technology sectors and is no longer a low-wage region, and so can compete neither in the high-technology sectors associated with information and communication technologies nor in low-skilled manufactures.

The long-term effects are not independent of the cyclical effects of commodity dependence. This implies that the structural vulnerabilities that are associated with commodity dependence are mixed with macroeconomic vulnerabilities. ${ }^{15}$ The basic reason for this is that the procyclical performance of macroeconomic variables induced by commodity price cycles may affect other economic activities. The cyclical patterns of spending associated with commodity booms generate positive effects, particularly on non-tradable sectors, and of course the opposite impact during crises. In contrast, the cyclical patterns of exchange rates that commodity prices generate-real appreciation during commodity booms, depreciation during crises-would tend to have negative effects on non-commodity tradable sectors (exporting and importcompeting manufacturing and some service activities) during booms and may increase the volatility in the profitability of investment in those sectors more generally. Firms in non-resource tradable sectors may actually go bankrupt during commodity booms, generating permanent effects on economic structures and productivity losses if productivity is associated with production experience (Krugman, 1990). These effects of commodity booms have been favourite topics of the 'Dutch Disease' literature.

It can be added that, beyond the structural and macroeconomic vulnerabilities mentioned, which are strictly economic pressures, there might be other vulnerabilities of a more political economy or institutional character. In this regard, the literature on the Dutch Disease as well as historical discussion in Latin America has focused on the institutional effects of the 'rentierism' associated with natural resources. There may also be important distributive effects,

14 One interesting analysis is the comparative history of Scandinavian vs. Latin American historical development, in the essays collected in Blomström and Meller (1991).

15 Ocampo and Parra-Lancourt (2007) indicate that the poor long-term growth performance of countries specialising in natural resources and natural resource-based manufactures may be associated with long periods of low commodity prices. 
associated with land concentration in the case of agriculture and high industrial concentration in the cases of hydrocarbons and mining. However, I would like to concentrate on strictly macroeconomic issues here.

\subsection{The Manifestation of Macroeconomic Dynamics in Latin America}

To analyse cyclical effects in the region, it may be useful to look at the Latin American business cycles over the past quarter century. Figure 4.6.A shows the tendency of aggregate private demand to move in a strong procyclical fashion, generating cycles that are stronger than those experienced by GDP - that is to say, stronger expansion during booms, stronger contraction during crises.

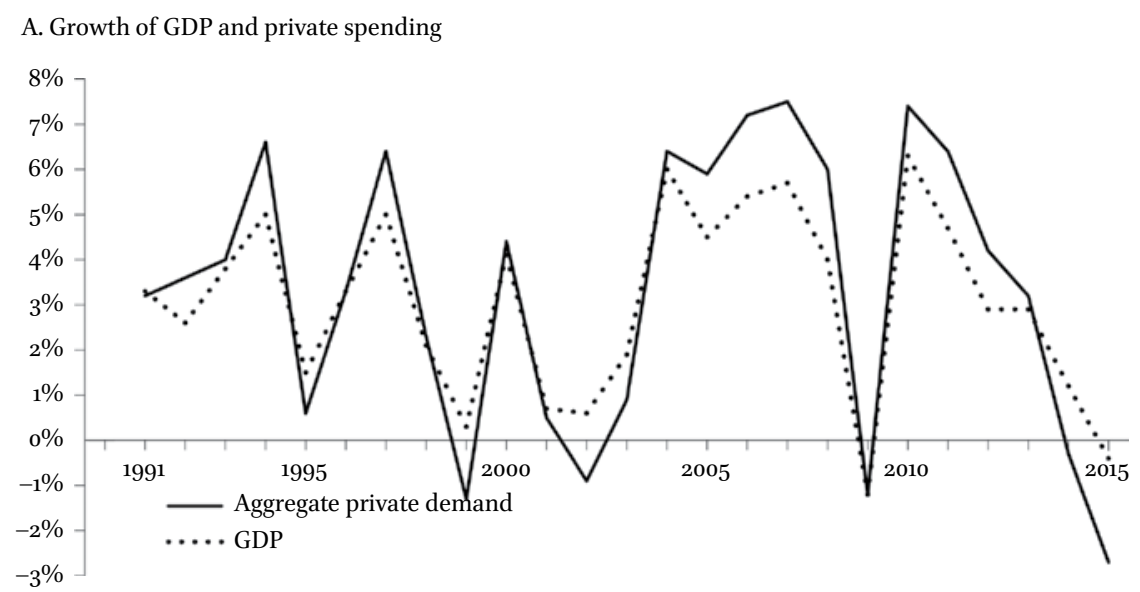

B. Current account balance, adjusted by terms of trade (\% of GDP)

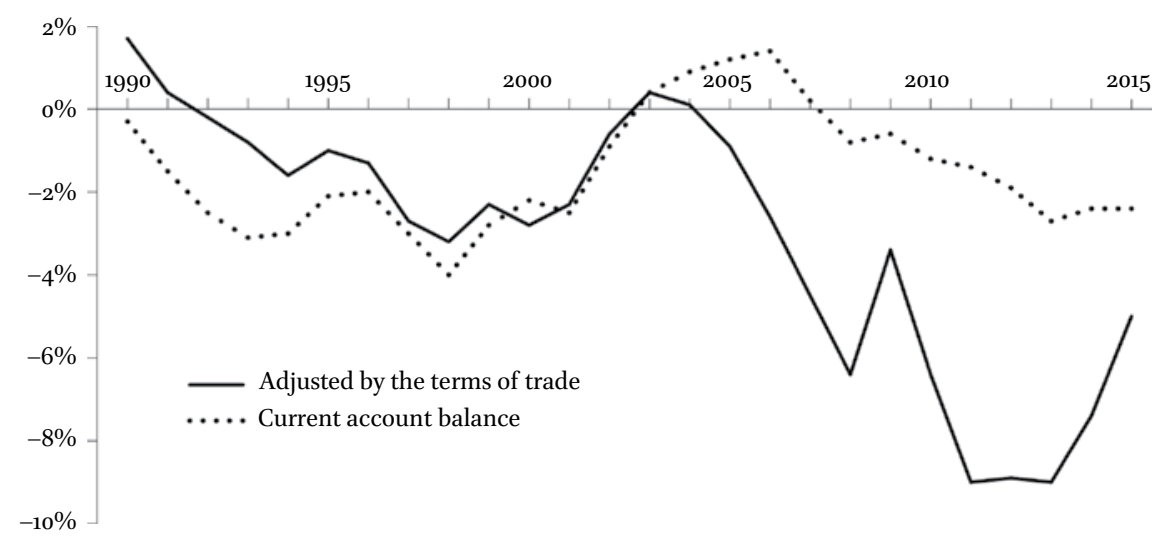

FIGURE 4.6 Macroeconomic cycles during the past quarter century. SOURCE: AUTHOR'S ESTIMATES BASED ON ECLAC DATA. 
These cycles were sharper during the long commodity boom of the early twenty-first century, as improvements in the terms of trade enhanced income growth, leading to a stronger expansion in aggregate demand. The recent contraction of demand has also been harsher.

Since the current account of the balance of payments is the difference between gross national income and aggregate spending, the relative movement between these two variables will be reflected in a tendency for that balance to deteriorate during expansions and to improve during crises (Figure 4.6.B). This is, therefore, the best evidence of the strong procyclical patterns of aggregate demand that characterise Latin America. The only exception to this was the early part of the commodity boom that started in 2004, which was reflected (by Latin American standards) in a very unusual current account surplus in the period 2003-07. This reflects, however, the rise in export values and gross national income generated by the improvement in the terms of trade. When export values are re-estimated using 2003 terms of trade, as indicated by the current account balance adjusted by the terms of trade in Figure 4.6.B, there was a clear deterioration even during those years. This was even worse after the North Atlantic financial crisis since, despite the massive gains from terms of trade-the difference between the normal and adjusted current account balance-Latin America ran current account deficits at current prices. What this implies is that Latin America not only spent the gains generated by the improvement of the terms of trade-a massive 51 per cent of GDP in the period 2004-14-but actually overspent the commodity boom. This conclusion is also reached by the IMF (2013) using a different methodology for calculating the gains from improvements in the terms of trade, which actually estimates even stronger gains.

Procyclical spending patterns are the basic reason why adjustment was so severe in the period 2014-16, as reflected in the very strong contraction of private demand and the adjustment of the current account adjusted by the terms of trade, particularly through the reduction in imports. In this regard, there is an essential difference between the conditions that prevailed before the North Atlantic financial crisis and those that were in place prior to the recent commodity crisis. Indeed, in the context of the former crisis, although aggregate demand was growing fast, the region had gone through five consecutive years of current account surpluses (2003-07), which were reflected in turn in falling debt ratios and an accumulation of large foreign exchange reserves. In contrast, the region faced the recent commodity crisis after five consecutive years of current account deficits (2008-13, again despite the terms of trade gains). This is, above all, a reflection of the incapacity of central banks and governments to smooth out the aggregate demand cycle. 
The fiscal balance had similar effects. So, as the ECLAC data show, the region faced the North Atlantic crisis after five years of primary fiscal surpluses (in this case, 2004-08) but faced the commodity crisis after several years of primary deficits (the only exception being the year 2011) and, of course, larger overall fiscal deficits. This relates, of course, to the question of whether fiscal policy is procyclical or countercyclical, a topic that has been the subject of extensive debate in recent years. Procyclical fiscal patterns tend to be the rule in emerging and developing countries, and certainly in Latin America. They are associated with procyclical patterns in the availability of finance but also with the political economy pressures to spend rising public sector revenues during booms. It is important to underscore that political economy pressures are more difficult to handle if austerity policies have been in place during the previous crisis: procyclical austerity policies during crises will tend to induce procyclical spending policies when fiscal balances are restored and public sector revenues recover.

These effects are enhanced in commodity-dependent countries by the reliance on fiscal revenues originating in natural resource-intensive sectors, both from corporate income taxes and royalties, but also from the profits of stateowned activities in these sectors. Table 4.2 summarises the fiscal dependence of different Latin American countries on revenues from natural resources. As is clear, the Andean economies have the highest fiscal dependence on hydrocarbon revenues (Venezuela, Ecuador, Bolivia and, to a lesser extent, Colombia),

TABLE 4.2 Fiscal dependence on natural resource revenues (\% of total government revenues)

\begin{tabular}{|c|c|c|c|c|c|c|}
\hline & \multicolumn{3}{|c|}{ Hydrocarbon revenues } & \multicolumn{3}{|c|}{ Mining revenues } \\
\hline & 2000-03 & $2005^{-08}$ & 2010-13 & 2000-03 & $2005^{-08}$ & $2010-13$ \\
\hline Argentina & 10.5 & 10.9 & $7 \cdot 3$ & 0.0 & 0.4 & 0.5 \\
\hline Bolivia & 20.6 & $35 \cdot 7$ & 34.4 & 0.3 & 2.1 & 3.2 \\
\hline Brazil & 8.4 & 9.2 & 7.2 & 0.1 & 0.5 & 0.7 \\
\hline Chile & & & & 4.0 & $27 \cdot 7$ & $15 \cdot 3$ \\
\hline Colombia & 6.7 & 8.2 & 12.6 & 0.6 & 1.6 & 1.3 \\
\hline Ecuador & $29 \cdot 3$ & $35 \cdot 3$ & 40.3 & & & \\
\hline Mexico & 30.2 & $33 \cdot 9$ & $29 \cdot 3$ & 0.3 & 0.8 & 1.0 \\
\hline Peru & 12.0 & 10.0 & $9 \cdot 7$ & 1.0 & 10.6 & $7 \cdot 4$ \\
\hline Venezuela & 50.0 & 51.2 & $45 \cdot 5$ & & & \\
\hline
\end{tabular}

SOURCE: ECLAC (2015A), CHAPTER 2. 
mining revenues (Chile) or a mix of the two (Peru). Mexico is also highly fiscally dependent on hydrocarbon revenues; Argentina's and Brazil's hydrocarbon dependence is only moderate.

The discussion on whether Latin American countries have 'graduated' from procyclical fiscal policies has been extensive in recent years..$^{16}$ There has certainly been progress. It includes the expansionary fiscal policies adopted by several countries to mitigate the effects of the North Atlantic financial crisis, and the design of fiscal rules that take into account both the cyclical performance of tax revenues in general and the fiscal effects of commodity price fluctuations. Chile introduced rules of this sort in 2000 and Colombia did so in 2011. ${ }^{17}$ However, leaving aside the countercyclical response of several countries to the North Atlantic crisis, a look at the full cycle that preceded and ended with that crisis shows that the number of countries following countercyclical fiscal policies was relatively small (Ocampo, 2012). And the fact that most commodity-dependent countries adopted contractionary fiscal policies during the recent commodity downswing indicates that advances in this area have been limited.

Long-term effects are better seen in terms of GDP growth patterns, including a comparison with the period of state-led industrialisation as well as division by subregions, which take into account the greater recent commodity dependence of South America. Table 4.3 provides a simple comparison. ${ }^{18}$ Taken generally, growth slowed during the market reform period (1990-2015) in relation to the levels observed during state-led industrialisation (1950-80). This is particularly true of the two largest Latin American economies. If we exclude these two countries, the slowdown was less marked. In the case of South America, the more moderate slowdown was closely associated with the weak growth of the Southern Cone countries (Argentina, Chile and Uruguay), which

16 A positive view of their advance into countercyclical fiscal policy is that presented by Végh and Vuletin (2014) and, to a lesser extent, Céspedes and Velasco (2014). In contrast, Klemm (2014) finds that fiscal policy has been procyclical on average in Latin American countries once the effect of commodity prices is included in the fiscal balance, with the IMF (2013) and Celasun et al. (2015) reinforcing the view of limited, if any, advance.

17 In the past, Colombia also successfully managed the National Coffee Fund, created in 1940, in a countercyclical way. However, with the collapse of the International Coffee Agreement in 1989 the country's capacity to use this instrument weakened considerably, and in any case coffee does not represent the share of the economy that it once did.

18 Given the demographic 'bonus' of recent years and what may be called the demographic 'tax' experienced in the 1950s and 1960s, comparisons of total GDP growth outperform those of GDP per capita. An alternative is to use GDP per worker, which tends to reinforce the preference for overall GDP comparisons. 
TABLE 4.3 GDP growth (in percentage), Latin America and its sub-regions

\begin{tabular}{lcllllr}
\hline & $\mathbf{1 9 5}-\mathbf{8 0}$ & $\mathbf{1 9 9 0 - 1 5}$ & $\mathbf{2 0 0 3}-\mathbf{1 3}$ & $\mathbf{2 0 0 3}-\mathbf{0 8}$ & $\mathbf{2 0 0 8 - 1 3}$ & $\mathbf{2 0 1 3}-\mathbf{1 5}$ \\
\hline Latin America & $5.5 \%$ & $3.1 \%$ & $4.1 \%$ & $5.2 \%$ & $2.9 \%$ & $0.7 \%$ \\
South America & $5.1 \%$ & $3.1 \%$ & $4.6 \%$ & $6.0 \%$ & $3.3 \%$ & $-0.3 \%$ \\
Brazil & $7.0 \%$ & $2.6 \%$ & $3.7 \%$ & $4.7 \%$ & $2.6 \%$ & $-1.7 \%$ \\
Excluding Brazil & $4.0 \%$ & $3.6 \%$ & $5 \cdot 5 \%$ & $7.2 \%$ & $3.9 \%$ & $0.9 \%$ \\
Mexico and Central & $6.4 \%$ & $3.0 \%$ & $2.9 \%$ & $3.7 \%$ & $2.2 \%$ & $2.7 \%$ \\
America & & & & & & \\
Mexico & $6.6 \%$ & $2.7 \%$ & $2.6 \%$ & $3.4 \%$ & $1.9 \%$ & $2.3 \%$ \\
Excluding Mexico & $5.1 \%$ & $4.5 \%$ & $4.7 \%$ & $5.7 \%$ & $3.7 \%$ & $4.6 \%$ \\
& & & & & & \\
\hline
\end{tabular}

SOURCE: AUTHOR'S ESTIMATES BASED ON ECLAC DATA.

were the poorest performers (together with Bolivia) during the period of stateled industrialisation. In the case of Central America, the political conflicts experienced by certain countries at the end of that period also tended to reduce growth.

As expected, the benefits from the 2003-13 commodity boom were captured by South America, which on average grew 1.5 percentage points faster than in the post-reform period as a whole (1.9 points if we exclude Brazil). Stronger growth was a feature of the first part of the boom (2003-08), rather than of the second part (2008-13); in fact, growth in the period 2008-13 was not much different from the post-reform average. In any case, the correlation between commodity prices and growth must be taken with a grain of salt, as Figure 4.7 indicates. ${ }^{19}$ Although the correlation is positive, country-specific experiences have been extremely diverse, indicating that domestic policies and national structural factors (notably those affecting the largest economies of the region) may have been more important. So, among the South American economies, the good overall performance of Argentina, Peru and Uruguay in the period 2003-13 and the poor performance of Brazil cannot be explained by the intensity of the commodity boom. In turn, there is an ever larger divergence in experience among the small economies, which generally experienced adverse terms of trade shocks.

19 The correlation would be further weakened if we take into account the fact that the apparently good performance of Venezuela in the period 2003-13 was enhanced by a strong recession in that country in the period 2002-03, associated to a large extent with a strike at the state-owned oil company. 


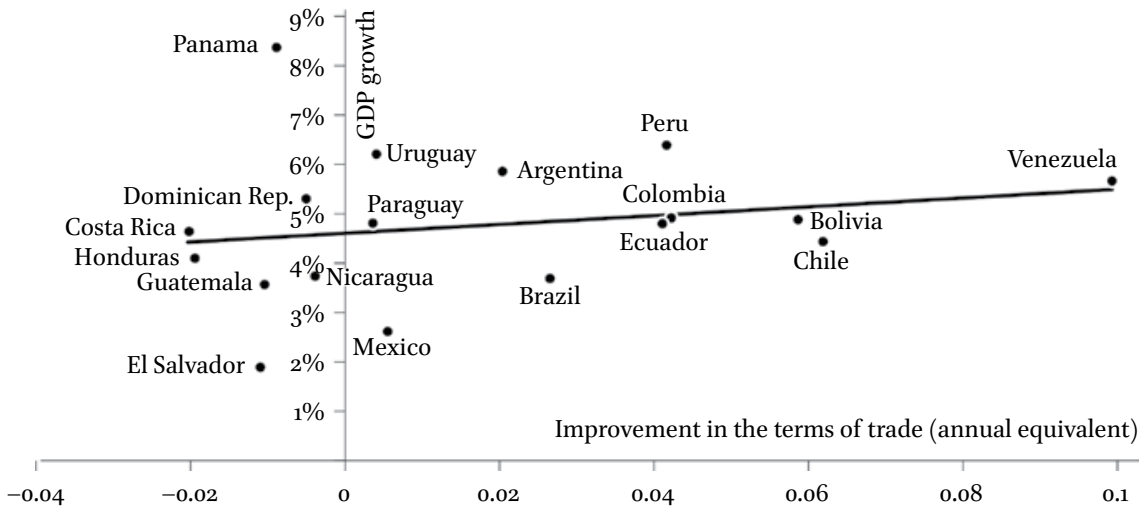

FIGURE 4.7 Correlation between GDP growth and improvements in the terms of trade, 2003-2013. SOURCE: AUTHOR'S ESTIMATES BASED ON ECLAC DATA.

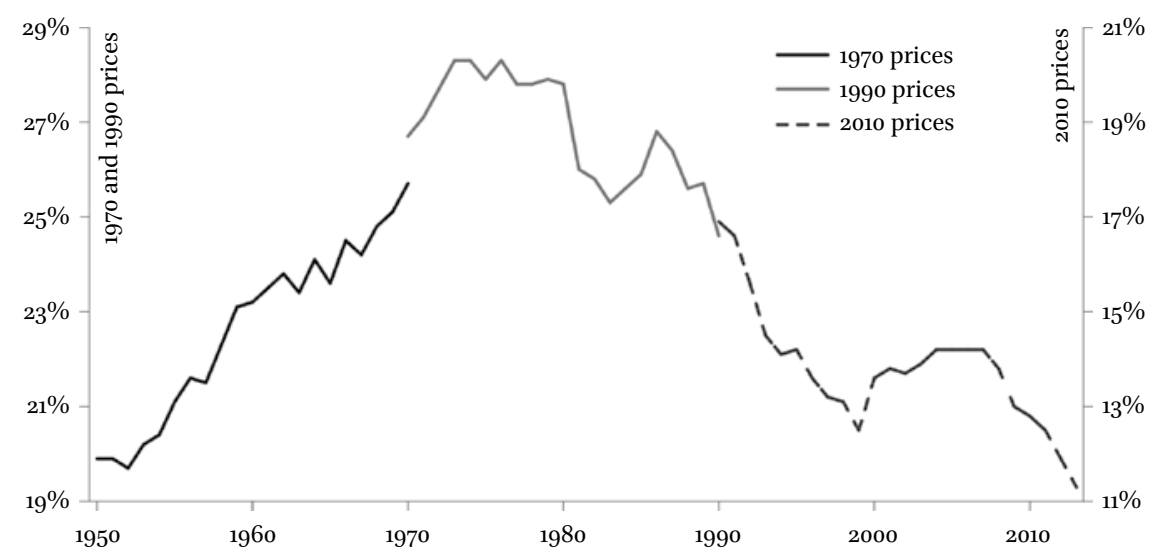

FIGURE 4.8 Share of manufacturing in GDP, 1950-2013. SOURCE: ECLAC.

Trends in industrialisation are part of the explanation for performance in different periods (Figure 4.8). The increasing share of manufacturing production in GDP (industrialisation coefficient, as we will call it here) was a strong and continuous process during state-led industrialisation, reinforced in different ways through the commodity cycle: by demand-cum-protection and foreign exchange availability during upswings, and by import substitution and export promotion policies during the downswing of the second half of the $1950 \mathrm{os}$ and the 1960 s (Bértola and Ocampo, 2012, Chapter 4). The rise in the share of manufacturing came to an end in the mid-1970s, in the midst of a commodity and debt boom, indicating some (though still weak) Dutch Disease effects. The 
collapse of the industrialisation coefficient took place partly as a result of the debt crisis of the 1980s, but particularly as a result of market reforms.

With regard to the 2003-13 commodity boom, better performance during its early phase (2003-08) may be associated with the stronger growth of manufacturing production, which contrasts with the collapse of the industrialisation coefficient during the second phase of the boom (2008-13). In fact, the early phase of the boom is a rare exception to the downward trend of the industrialisation coefficient since the 1980 s, no doubt associated with a relatively competitive real exchange rate. ${ }^{20}$ In contrast, the second phase of the boom was characterised by renewed and rapid deindustrialisation, associated in turn with fairly strong Dutch Disease effects generated by strong and fairly broadly spread exchange rate overvaluation, as well as by massive imports from China (Gallagher, 2016). This is on top of the negative technological gap that the region increasingly suffers from, not only in relation to East Asian economies but also to natural resource-dependent developed countries (see, among many others, ECLAC, 2012). What this also implies is that, in contrast to Pérez's (2010) analysis, and a few successful experiences aside, the region has failed to appropriate the full technological benefits of the exploitation of its natural resources.

\section{5}

\section{Conclusions}

Overall, Latin America-and, particularly, South America-has been unable to fully capture the benefits of its natural resource specialisation and has faced, in contrast, some negative structural effects of such dependence, notably deindustrialisation. Even more importantly, it has been a notable victim of the macroeconomic vulnerabilities generated by commodity cycles, largely because it has failed to develop the appropriate countercyclical macroeconomic policies. The lack of countercyclical policies was prominently reflected in the slowdown of South American countries' economies in the period 2008-13, which occurred despite the continuing commodity boom and was associated to a large extent with exchange rate overvaluation and renewed deindustrialisation trends. Furthermore, procyclical policies during the boom generated strong vulnerability to the collapse of commodity prices that has taken place in recent years.

20 According to the rates estimated by ECLAC, real exchange rates in South American countries were more competitive in the period 2003-08 than in the period 1990-2013 as a whole, except in Ecuador and Venezuela. They then experienced a strong appreciation in most countries between 2009-13. 
This implies that the way forward, in the context of the negative phase currently being experienced by commodity prices, requires a very active strategy for the production sector, with technological development at its centre. This strategy must, at its core, blend an active search for production diversification with an explicit policy of reindustrialisation, but also with a commitment to fully exploiting the linkages and technological opportunities provided by the region's natural resource wealth.

\section{References}

Anderson, K. and A. Valdés (2008) 'Introduction and Summary', in K. Anderson and A. Valdés (eds.) Distortions to Agricultural Incentives in Latin America (Washington, D.C.: World Bank), pp. 1-58.

Bértola, L. and J.A. Ocampo (2012) The Economic Development of Latin America since Independence (Oxford: Oxford University Press).

Blomström, M. and P. Meller (eds.) (1991) Diverging Paths: Comparing a Century of Scandinavian and Latin American Economic Development (Washington, D.C.: InterAmerican Development Bank, and John Hopkins University Press).

Bresser-Pereira, L.C., J.L. Oreiro and N. Marconi (2015) Developmental Macroeconomics: New Developmentalism as a Growth Strategy (Milton Park: Routledge).

Bulmer-Thomas, V. (2014) The Economic History of Latin America since Independence (3rd ed.) (Cambridge: Cambridge University Press).

Cárdenas, E., J.A. Ocampo and R. Thorp (eds.) (2000) Industrialization and the State in Latin America: The Postwar Years, Volume 3 of An Economic History of Twentieth-Century Latin America (Houndmills: Palgrave, in association with St. Antony's College, Oxford).

Celasun, O., F. Grigoli, K. Honjo, J. Kapsoli, A. Klemm, B. Lissovolik, J. Luksic, M. Moreno Badia, J. Pereira, M. Poplawski-Ribeiro, B. Shang and Y. Ustyugova (2015) 'Fiscal Policy in Latin America: Lessons and Legacies of the Global Financial Crisis', IMF Staff Discussion Notes No. 15/6 (Washington, D.C.: IMF).

Céspedes, L.F. and A. Velasco (2014) 'Was this Time Different?: Fiscal Policy in Commodity Republics', Journal of Development Economics, 106, pp. 92-106, DOI: 10.1016/ j.jdeveco.2013.07.012.

ECLAC (Economic Commission for Latin America and the Caribbean) (2015a) América Latina y el Caribe y China: Hacia una nueva era de cooperación económica (Santiago de Chile: ECLAC).

ECLAC (2015b) Balance Preliminar de las economías de América Latina y el Caribe (Santiago de Chile: ECLAC). 
ECLAC (2012) Cambio estructural para la equidad: Una visión integrada del desarrollo (Santiago de Chile: ECLAC).

ECLAC (2001) A Decade of Light and Shadow: Latin America and the Caribbean in the 1990 (Santiago de Chile: ECLAC).

Erten, B. and J.A. Ocampo (2013) 'Super Cycles of Commodity Prices since the Mid-Nineteenth Century', World Development, 44, pp. 14-30, DOI: 10.1016/j. worlddev.2012.11.013.

French-Davis R., O. Muñoz and G. Palma (1998) 'The Latin American Economies, 1959-199o', in L. Bethell (ed.) The Cambridge History of Latin America, Latin America: Economy and Society Since 1930 (vol. 6) (Cambridge: Cambridge University Press).

Gallagher, K.P. (2016) The China Triangle: Latin America's China Boom and the Fate of the Washington Consensus (New York: Oxford University Press).

Grilli, E. and M. Ch. Yang (1988) 'Primary commodity prices, manufactured goods prices, and the terms of trade of developing countries: What long run shows', The World Bank Economic Review, 2(1).

Hausmann, R. (2011) 'Structural Transformation and Economic Growth in Latin America', in J.A. Ocampo and J. Ros (eds.) The Oxford Handbook of Latin American Economics (Oxford: Oxford University Press), chapter 21.

IMF (International Monetary Fund) (2013) World Economic and Financial Surveys, Regional Economic Outlook, Western Hemisphere: Time to Rebuild Policy Space (Washington, D.C.: IMF).

Klemm, A. (2014) 'Fiscal Policy in Latin America over the Cycle', IMF Working Paper, No. $14 / 59$.

Krugman, P. (1990) Rethinking International Trade (Cambridge M.A.: MIT Press).

Lewis, W.A. (1978) Growth and Fluctuations, 1870-1913 (London: George Allen and Unwin).

Lewis, W.A. (1969) Aspects of Tropical Trade, 1883-1965 (Stockholm: Almqvist \& Wiksell, Serie Wicksell Lectures).

Ocampo, J.A. (2012) 'How Well Has Latin America Fared During the Global Financial Crisis?', in M. Cohen (ed.) The Global Economic Crisis in Latin America: Impacts and Prospects (Milton Park: Routledge), chapter 2.

Ocampo, J.A. (1986) 'New Developments in Trade Theory and LDCs', Journal of Development Economics, 22(1), pp. 129-170, DOI: 10.1016/0304-3878(86)90054-4.

Ocampo, J.A. and M.A. Parra-Lancourt (2010) 'The Terms of Trade for Commodities since the Mid-Nineteenth Century', Revista de Historia Económica-Journal of Iberian and Latin American Economic History, 28(1), pp. 11-37, DOI: 10.1017/ So212610909990085.

Ocampo, J.A. and M.A. Parra-Lancourt (2007) 'The Dual Divergence: Growth Successes and Collapses in the Developing World Since 1980', in Ffrench-Davis, R. and J.L. 
Machinea (eds.) Economic Growth with Equity: Challenges for Latin America (Houndmills: Palgrave, and ECLAC).

Palma, G. (2011) 'Why Has Productivity Growth Stagnated in Latin America since the Neo-Liberal Reforms?', in J.A. Ocampo and J. Ros (eds.) The Oxford Handbook of Latin American Economics (Oxford: Oxford University Press), chapter 23.

Pérez, C. (2010) 'Dinamismo tecnológico e inclusión social en América Latina: Una estrategia de desarrollo productivo basada en los recursos naturales', Revista de la CEPAL, 100, pp. 123-145.

Prebisch, R. (1973) Interpretación del proceso de desarrollo latinoamericano en 1949, 2nd ed. (Santiago: ECLAC, Serie conmemorativa del XXV aniversario de la CEPAL).

Rodrik, D. (2014) 'The Past, Present and Future of Economic Growth', in F. Allen et al. (eds.) Toward a Better Global Economy (Oxford: Oxford University Press), chapter 2. Schumpeter, J.A. (1939) Business Cycles (New York: McGraw-Hill).

Singer, H.W. (1950) 'U.S. foreign investment in underdeveloped areas: The distribution of gains between investing and borrowing countries', American Economic Review, Papers and Proceedings, 40.

Végh, C. and G. Vuletin (2014) 'The Road to Redemption: Policy Response to Crisis in Latin America', IMF Economic Review, 62(4), pp. 526-568, DOI: 10.1057/imfer.2014.23. 